\title{
FERTILIZATION AND CROPPING SYSTEMS: PERFORMANCE AND OIL CONTENT OF BASIL VARIETIES
}

\author{
FERTILIZAÇÃO E SISTEMAS DE CULTIVO: DESEMPENHO E TEOR DE OLEO DE \\ VARIEDADES DE MANJERICÃO
}

\begin{abstract}
Adeláide Siqueira SILVA ${ }^{1}$; Roberta Camargos OLIVEIRA² ${ }^{2}$ José Magno Queiroz LUZ ${ }^{3}$; Sérgio Macedo SILVA ${ }^{4}$; Arie Fitzgerald BLANK ${ }^{5}$; Mércia Freitas ALVES ${ }^{1}$; Regina Maria Quintão LANA ${ }^{3}$

1. Pós-doutorando em Agronomia Instituto de Ciências Agrárias da Universidade Federal de Uberlândia-ICIAG-UFU, Uberlândia, MG, Brasil; 2. Pós-doutoranda na Universidade Federal de Sergipe-UFS, Av. Marechal Rondon s/n, São Cristóvão-SE, Brasil, robertacamargoss@gmail.com; 3. Professor do ICIAG-UFU, Uberlândia, MG, Brasil; 4. Professor do Instituto de Ciências Agrárias da Universidade Federal dos Vales do Jequitinhonha e Mucuri-ICA-UFVJM, Unaí-MG, Brasil; 5. Professor do Departamento de Engenharia Agronômica da UFS, Av. Marechal Rondon s/n, São Cristóvão-SE, Brasil
\end{abstract}

\begin{abstract}
Sweet basil (Ocimum basilicum L.) is an aromatic and medicinal crop that produces metabolites rich in chemical constituents for various purposes. The composition of the essential oil is variable due to external factors during production, such as fertilization and the environment, and the oil concentration may vary even among the genotypes of a species. For sweet basil mores studies are needed to clarify understanding about the biomass and essential oil yield and nutrient management. The objective of this study was to evaluate the biomass and essential oil yield of basil varieties with organo-mineral fertilizer under different agricultural systems. The experimental design was a randomized complete block (DBC), with three replications, in a 2X4 factorial scheme, with two varieties (Maria Bonita and Genovese) and four fertilizations (50 and 100\% organo-mineral, one mineral source and one organic source). Two areas were carried out simultaneously (greenhouse and field) to evaluate plant height, fresh biomass, essential oil content, yield and chemical composition. Results indicate that Genovese showed superior height and biomass yield when mineral or organic fertilizer was used at the greenhouse. Organo-mineral and organic fertilizers provided significantly better results of biomass yield in both varieties at field cultivation. The oil content was higher in the field, reflecting higher oil yields in field treatments in comparison to greenhouse. We concluded that the environment of cultivation and the way fertilizer sources release the nutrients can be determinan factors in the performance of basil plants; without protected cultivation, the content of essential oil is higher and the organo-mineral fertilizer can provide better nutrient supply to the plants mainly during rainy season.
\end{abstract}

KEYWORDS: Aromatic plants. Nutrient availability, Organomineral fertilizer.

\section{INTRODUCTION}

Ocimum basilicum $\mathrm{L}$. is among the species most investigated as a source of essential oils, highly valued by the pharmaceutical and cosmetics industries. Its characteristic aroma is due to its chemical composition, with several organoleptic qualities, with this species much appreciated in traditional foods, sauces and salads (MIRZAJANI et al., 2015). It also has several insecticidal, nematicidal, fungicidal and antimicrobial properties (POPOVIC et al., 2013; SILVA et al., 2017a), which makes it the object of further studies.

The essential oil composition of aromatic species is determined mainly by the plant genotype, but environmental and propagation conditions can also cause a significant impact on the production of these compounds (DEMISSIE et al., 2011). Sellami et al. (2009) reported that the soil characteristics and the conditions of cultivation can affect the production of biomass and the essential oils composition. Many studies gave attention to the soil conditions and the association with fertilizers that result in the best yield of essential oils by the species and its varieties.

Concerning nutrient management, several studies presented favorable responses to the use of chemical fertilizers (ONWU et al., 2014), organic materials (BUFALO et al., 2015; PRADEEPKUMAR et al., 2017) and the combination between them (SINGH et al., 2014; SILVA et al., 2017b). However, it is necessary to be clear about what makes a huge impact in plant development, which is related to quantity and quality of the sources of the organic and inorganic components (PRADEEPKUMAR et al., 2017).

Chemical fertilizers provide readily available nutrients in the soil, are easily assimilated 
by plants, and can generate a rapid response after application (RAIJ, 2011). But continuous use of these fertilizers often leads to unsustainability in crop production and creates a deficiency of certain nutrients in the soil and causes environmental pollution. For aromatic and perennial plants it is necessary to provide more time of exposure of the nutrients in the soil, mainly during the rainy seasons in tropical regions like Brazil.

Sustainability of organic nutrition in vegetable crops depends on the quantity and quality of organic manures applied, crop yield, quality and price of the produce. This fertilizer presents unquestionable soil conditioning effect and is an indicator of natural fertility, with improved soil conditions and greater presence of nutrients during longer period of cultivation (SILVA et al., 2017a). This is the main advantage of using this fertilizer for aromatic plants compared to other sources such as mineral fertilizers.

Organic compounds can stimulate physiological functions, and enhance several metabolic pathways, including those that synthesize secondary compounds (ONOFREI et al., 2017) and biosynthesis of gibberellin and regulation of several metabolic and transport functions (RAFIEE et al., 2013).

Recently, a new formulation of fertilizers at the junction of mineral and organic sources has been developed to improve the potential of crop production. Due to the presence of organic parts, organo-mineral fertilizers allow better retention of nutrients in the soil due to the high capacity of cation exchange. These characteristics cause less leaching of nutrients to the soil and better availability of nutrients for the root system because the fertilizers release nutrients more slowly to the soil solution (CERRI, 2011), in comparison to the mineral sources.

For medicinal and aromatic plants that are cultivated during many years on the same area of soil, this new formulation can be a better choice to improve nutrient availability. The current trend is aimed at exploring the possibility of supplementing chemical fertilizers with ecological ones that are ecofriendly and cost-effective (ARAB et al., 2015).

However, knowing the needs of cultivars is essential for efficient management of agroecosystems, and with balanced fertilization, the crops can naturally provide sustainability (CHEN et al., 2017; JI et al., 2015). Particularly for basil, there is a lack of information on the performance of varieties using new fertilizer formulations, such as organo-mineral, mainly under protected cultivation or during different seasons. Therefore, this work aimed to evaluate the biomass and essential oil yield of basil varieties with organo-mineral fertilization in different agricultural systems.

\section{MATERIAL AND METHODS}

\section{Experimental areas}

The experiments were carried out in two experimental areas (field and greenhouse), at the Research Farm "Glória", located in the municipality of Uberlândia, State of Minas Gerais, Brazil. The data of temperature, humidity, solar radiation and accumulated rainfall are in Figure 1. The experiments were carried out from early spring, in 2014, simultaneously in both environments, until late summer of the next year.

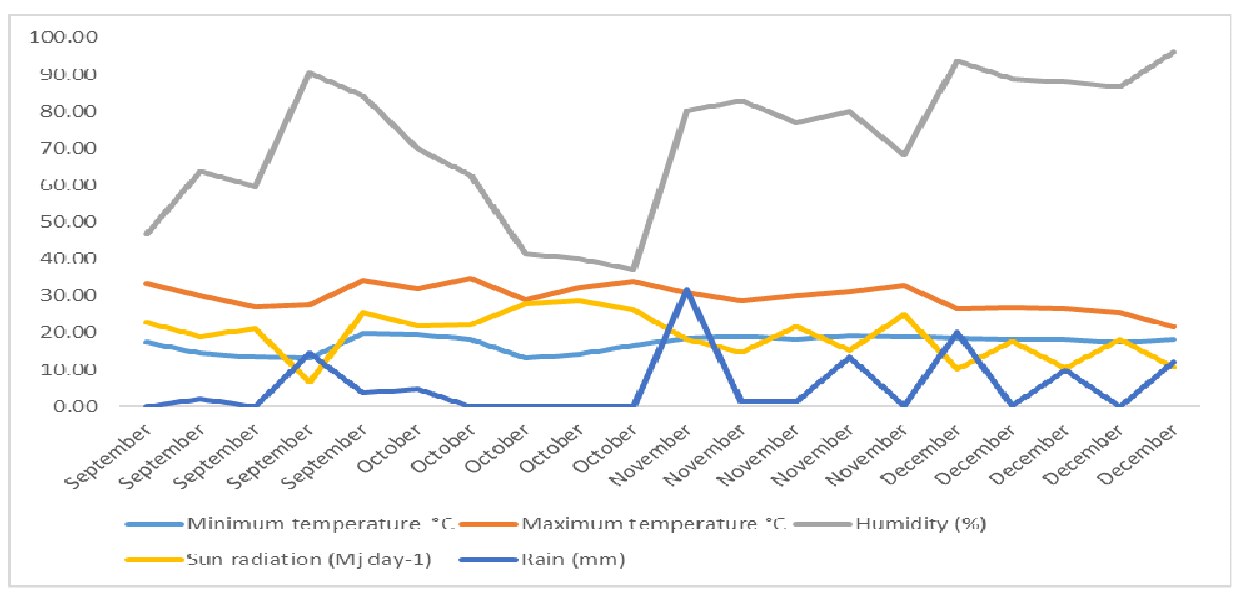

Figure 1. Means of weather conditions during the field experiments

\section{Experimental design and treatments}

Each experiment was conducted in a randomized block design, with three replications in factorial scheme $2 \times 4$, with two varieties of sweet basil chemotype linalool (Maria Bonita and Genovese) and four fertilizations: 2 rates of the 
organo-mineral (100\% and 50\%), one mineral source and one organic source. The plots presented three lines with 7 plants each. The spacing was $60 \mathrm{~cm}$ between rows and $45 \mathrm{~cm}$ between plants.

"Maria Bonita" was obtained from the access PI 197442, originating from the Germplasm Bank of North Central Regional PI Station, Iowa State University, from United States of America. Seeds were obtained from the Program of Breeding of Aromatic Plant of Federal University of Sergipe. "Genovese" was obtained from Isla Sementes ${ }^{\circledR}$. This is considered a shrub with height between 45 to $90 \mathrm{~cm}$, very branched, and presenting many flowers.

The pelletized organo-mineral fertilizer was manufactured by the company Geociclo Biotecnologia S/A, in Brazil. The compound received mineral nutrients, such as urea, monoammonium phosphate (MAP), and potassium chloride $(\mathrm{KCl})$, and through an industrial process it was transformed into an organo-mineral fertilizer. The organo-mineral fertilizers were produced using a biodegradable water soluble organic polymer, in order to gradually release the nutrients.

In the experiment, we used 500 and $250 \mathrm{~kg}$ $\mathrm{ha}^{-1}$ of the formulated organo-mineral fertilizer (100 and 50\%) with the following characteristics: $4 \%$ total nitrogen; $14 \% \mathrm{P}_{2} \mathrm{O}_{5} ; 8 \%$ total potassium (NPK 4-14-8); $8 \%$ organic carbon; $10 \%$ humidity; $\mathrm{pH} 6$; density of $0,9 \mathrm{~g} \mathrm{~cm}^{-3}$; and cation exchange capacity of $175.5 \mathrm{mmol} \mathrm{kg}$. . The recommendation of McNaughton (2006) for aromatic plants was used.

Mineral fertilizer was used by applying 500 $\mathrm{kg} \mathrm{ha}^{-1}$ of the formulated fertilizer NPK 4-14-8, with $4 \%$ total nitrogen (Urea), $14 \% \quad \mathrm{P}_{2} \mathrm{O}_{5}$ (phosphate monoammonium), $8 \%$ total potassium (potassium chloride).

Organic fertilizer was used by applying $8 \mathrm{t}$ $\mathrm{ha}^{-1}$. The chemical composition of the cattle manure presented the following values: $\mathrm{pH}=6,10$; Nitrogen $=1.76 \%$; Organic matter $=76.61 \%$; Organic carbon $=29.79 \%$; Relation $\mathrm{C} / \mathrm{N}=17 / 1 ; \mathrm{P}_{2} \mathrm{O}_{5}=0.46 \% ; \mathrm{K}_{2} \mathrm{O}$ $=1.95 \% ;$ Calcium $=2.14 \% ;$ Magnesium $=0.19 \%$; Sulfur $=0.11 \%$; Boron $=36 \mathrm{mg} \mathrm{kg}^{-1} ;$ Copper $=16$ $\mathrm{mg} \mathrm{kg}^{-1} ;$ Iron $=2898 \mathrm{mg} \mathrm{kg}^{-1} ;$ Manganese $=48 \mathrm{mg}$ $\mathrm{kg}^{-1}$; Zinc $=43 \mathrm{mg} \mathrm{kg}^{-1}$ and Sodium $=450 \mathrm{mg} \mathrm{kg}^{-1}$. The recommendation for vegetable crops was used according to Ribeiro; Diniz (2008).

\section{Soil analysis}

Before tillage, soil samples were collected. According to the soil analysis, field and greenhouse environments had the following characteristics: 1) Field: pH 5.7; $\mathrm{P}=235 \mathrm{mg} \mathrm{dm}^{-3} ; \mathrm{K}=189 \mathrm{mg} \mathrm{dm}^{-3}$; $\mathrm{Ca}^{2+}=6 \mathrm{cmol}_{\mathrm{c}} \mathrm{dm}^{-3} ; \mathrm{Mg}^{2+}=1.3 \mathrm{cmol}_{\mathrm{c}} \mathrm{dm}^{-3} ; \mathrm{Al}^{3+}=$ $0 \mathrm{cmol}_{\mathrm{c}} \mathrm{dm}^{-3} ; \mathrm{H}+\mathrm{Al}=3.4 \mathrm{cmol}_{\mathrm{c}} \mathrm{dm}^{-3} ;$ Sum of base $=$ $8 \mathrm{cmol}_{\mathrm{c}} \mathrm{dm}^{-3}$; cation exchange capacity $=11.13$ $\mathrm{cmol}_{\mathrm{c}} \mathrm{dm}^{-3}$; base saturation $=65 \%$; organic matter $=9.8 \mathrm{dag} \mathrm{kg}^{-1}$; and organic carbon $=5.7 \mathrm{dag} \mathrm{\textrm {kg } ^ { - 1 }}$; 2) Greenhouse: $\mathrm{pH} 6.0 ; \mathrm{P}=250.9 \mathrm{mg} \mathrm{dm}^{-3} ; \mathrm{K}=270$ $\mathrm{mg} \mathrm{dm}{ }^{-3} ; \mathrm{Ca}^{2+}=7.1 \mathrm{cmol}_{\mathrm{c}} \mathrm{dm}^{-3} ; \mathrm{Mg}^{2+}=2.5 \mathrm{cmol}_{\mathrm{c}}$ $\mathrm{dm}^{-3} ; \mathrm{Al}^{3+}=0 \mathrm{cmol}_{\mathrm{c}} \mathrm{dm}^{-3} ; \mathrm{H}+\mathrm{Al}=3.0 \mathrm{cmol}_{\mathrm{c}} \mathrm{dm}^{-3}$; $\mathrm{SB}=10.1 \mathrm{cmol}_{\mathrm{c}} \mathrm{dm}^{-3} ; \mathrm{T}=12.1 \mathrm{cmol}_{\mathrm{c}} \mathrm{dm}^{-3} ; \mathrm{V}=77$ $\% ; \mathrm{OM}=8.0 \mathrm{dag} \mathrm{kg}^{-1}$; and $\mathrm{OC}=5.6 \mathrm{dag} \mathrm{kg}^{-1}$. Corrective application was not carried out in these areas.

\section{Plant material and fertilizers application}

To obtain the seedlings, sowing of two varieties was done in trays using conventional substrate for seedlings. Two seeds were used per cell. At 60 days after sowing, when the seedlings presented two or three pairs of true leaves, transplanting was performed to both areas.

Soil preparation of the two areas was carried out 60 days before transplanting. The planting groove formation of the seedlings was made following line spacing, and consequently the manual application of the fertilizers mentioned above was performed.

A drip irrigation system was installed with flow rate of $2.5 \mathrm{~L} \mathrm{~h}^{-1}$, spaced $0.75 \times 0.75 \mathrm{~m}$ between rows of plants. Irrigation was daily applied during 60 minutes in the first days after transplanting for establishment of the seedlings. During culture growth irrigation was applied every two days for 60 minutes. The field cultivation had the same drip irrigation, but during the rainy days, the irrigation was not carried out. There was no pest and disease infestation in the plants and so there was no application of pesticides throughout the experimental period.

\section{Harvests and evaluations}

Harvest was performance at 92 days after planting at early summer, and only when more than $50 \%$ of the plants presented open flowers. Before the harvest, the heights of the plants of the central line of each plot were obtained. Harvest consisted of cutting the plants at about $30 \mathrm{~cm}$ above the ground. Then, fresh material was weighed and stored for post analysis. The evaluated characteristics were: plant height, fresh biomass of plants (flowers and leaves), content, yield and chemical composition of the essential oil of both experiments.

\section{Extraction and chemical analysis of essential oil}

Essential oils were obtained by the hydrodistillation technique, using a modified Clevenger apparatus, as recommended by Ehlert et al. (2006). Each sample consisted of $120 \mathrm{~g}$ of fresh biomass (flowers and leaves) distilled for 120 minutes. The essential oils were collected, dried with anhydrous sodium sulfate $\left(\mathrm{Na}_{2} \mathrm{SO}_{4}\right)$, and stored 
in amber vials at $-20{ }^{\circ} \mathrm{C}$ until analysis of the chemical composition.

GC analyses of the essential oils were performed using gas chromatography coupled with mass spectrometry and flame ionization detection (GC-MS/FID; QP2010 Ultra, Shimadzu Corporation, Kyoto, Japan); the instrument was equipped with an autosampler AOC-20i (Shimadzu). Separations were accomplished using an Rtx®-5MS Restek-fused silica capillary column (5\%-diphenyl-95\%-dimethyl polysiloxane; $30 \mathrm{~m} \times$ $0.25 \mathrm{~mm}$ i.d., $0.25 \square \mathrm{m}$ film thickness) at a constant helium $(99.999 \%)$ flow rate of $1.2 \mathrm{~mL} / \mathrm{min}$. The essential oils were diluted in ethyl acetate and an injection volume of $0.5 \mu \mathrm{L} \quad(5 \mathrm{mg} / \mathrm{mL})$ was employed, with a split ratio of $1: 10$. The oven temperature was programmed to $50{ }^{\circ} \mathrm{C}$ (isothermal for $1.5 \mathrm{~min}$ ), with an increase of $4{ }^{\circ} \mathrm{C} / \mathrm{min}$ to 200 ${ }^{\circ} \mathrm{C}$, then $10{ }^{\circ} \mathrm{C} / \mathrm{min}$ to $250{ }^{\circ} \mathrm{C}$, ending with a $5 \mathrm{~min}$ isothermal at $250{ }^{\circ} \mathrm{C}$.

The MS and FID data were simultaneously acquired employing a Detector Splitting System; the split flow ratio was 4:1 (MS:FID). A $0.62 \mathrm{~m} \times 0.15$ $\mathrm{mm}$ i.d. restrictor tube (capillary column) was used to connect the splitter to the MS detector, and a 0.74 $\mathrm{m} \times 0.2 \mathrm{~mm}$ i.d. restrictor tube was used to connect the splitter to the FID detector. The MS data (total ion chromatogram, TIC) were acquired in full scan mode $(\mathrm{m} / \mathrm{z}$ of $40-350)$ at a scan rate of $0.3 \mathrm{scan} / \mathrm{s}$ using electron ionization (EI) with an electron energy of $70 \mathrm{eV}$. The injector temperature was 250 ${ }^{\circ} \mathrm{C}$, and the ion-source temperature was $250{ }^{\circ} \mathrm{C}$. The FID temperature was set to $250{ }^{\circ} \mathrm{C}$, and the gas supplies for the FID were hydrogen, air, and helium at flow rates of 30,300 , and $30 \mathrm{~mL} / \mathrm{min}$, respectively. Quantification of each constituent was estimated by FID peak-area normalization (\%). Compound concentrations were calculated from the GC peak areas, and they were arranged in order of GC elution.

Identification of individual components of the essential oil was performed by computerized matching of the acquired mass spectra with those stored in NIST21, NIST107 and WILEY8 mass spectral libraries of the GC-MS data system. A mixture of hydrocarbons $\left(\mathrm{C}_{9} \mathrm{H}_{20}-\mathrm{C}_{19} \mathrm{H}_{40}\right)$ was injected under these same conditions, and the identification of constituents was then performed by comparing the spectra obtained with those of the equipment data bank and according to the Retention Index, calculated for each constituent as previously described (ADAMS, 2007). Retention indices were obtained using the equation proposed by Van den Dool; Kratz (1963).

\begin{abstract}
Statistical analysis
Data were tested for residual normality assumptions (Shapiro-Wilk test) and for homogeneity between variances (Levene test). After this, treatment means were subjected to analysis of variance ( $\mathrm{F}$ test), followed by means tests (Tukey test).
\end{abstract}

\section{RESULTS}

\section{Height, fresh biomass, essential oil content and yield}

The results obtained showed that there is not significant interaction between varieties and fertilizers for all the evaluations at greenhouse and field areas (Table 1 and 2). Genovese showed significantly superior height to the Maria Bonita for all the fertilizers treatments at two experiments, and presented more biomass yield when mineral or organic fertilizers were used at the greenhouse. Low biomass yields were presented by the two rates of organo-mineral for both varieties at this same area.

On the other hand, at field cultivation, organo-mineral and organic fertilizers provided significantly better results of biomass yield to both varieties, in comparison to the mineral fertilizer.

The essential oil content at greenhouse presented significant differences between fertilizers but not between the varieties. High content of oil was obtained using $50 \%$ organo-mineral doses and the organic source.

The yield of essential oil in the greenhouse presented similar results to the oil content, and the organic fertilization provided the highest yields. Genovese differed significantly from Maria Bonitafor this same characteristic, being in this case a reflection of the greater amount of fresh biomass.

It was also observed that the oil content in the plants was higher in the field than in the greenhouse, which reflected higher oil yields in field treatments in comparison to greenhouse. 
Fertilization and cropping...

SILVA, A. S. et al.

Table 1. Means of plant height, biomass yield, concentration and yield of essential oil of Ocimum basilicum L. varieties at greenhouse cultivation.

\begin{tabular}{|c|c|c|c|c|c|}
\hline GREENHOUSE & & Height (cm) & & & \\
\hline Varieties & $\begin{array}{c}100 \% \\
\text { Organo-mineral }\end{array}$ & $\begin{array}{c}50 \% \\
\text { Organo-mineral }\end{array}$ & Mineral & Organic & Means \\
\hline Maria Bonita & 64.72 & 68.89 & 66.61 & 69.16 & $67.34 b$ \\
\hline Genovese & 92.77 & 97.28 & 93.89 & 98.25 & $95.50 \mathrm{a}$ \\
\hline Means & 78.75 & 83.08 & 80.25 & 83.61 & \\
\hline$F_{\text {value for variety }}$ & $14.7189 *$ & $\mathbf{F}_{\text {value for fertilizer }}$ & $0.995^{\mathrm{ns}}$ & & \\
\hline \multicolumn{6}{|c|}{ Biomass yield (g plant $\left.{ }^{-1}\right)$} \\
\hline Maria Bonita & 622.22 & 746.11 & 966.16 & 1295.33 & $907.45 b$ \\
\hline Genovese & 1036.94 & 1198.22 & 1708.33 & 1340.83 & $1321.08 \mathrm{a}$ \\
\hline Means & $829.58 \mathrm{~B}$ & $972.16 \mathrm{~B}$ & $1337.25 \mathrm{~A}$ & $1318.08 \mathrm{~A}$ & \\
\hline $\mathbf{F}_{\text {value for variety }}$ & $46.750 *$ & $\mathbf{F}_{\text {value for fertilizer }}$ & $17.534 *$ & & \\
\hline \multicolumn{6}{|c|}{ Essential oil concentration $(\%)$} \\
\hline Maria Bonita & 0.69 & 1.06 & 0.61 & 1.19 & 0.89 \\
\hline Genovese & 0.74 & 0.94 & 0.93 & 0.78 & 0.85 \\
\hline Means & $0.71 \mathrm{~B}$ & $1.00 \mathrm{~A}$ & $0.77 \mathrm{~B}$ & $0.98 \mathrm{~A}$ & \\
\hline$F_{\text {value for variety }}$ & $0.498^{\mathrm{ns}}$ & $F_{\text {value for fertilizer }}$ & $6.901^{*}$ & & \\
\hline \multicolumn{6}{|c|}{ Essential oil yield $\left(\mathrm{g} \mathrm{plant}^{-1}\right)$} \\
\hline Maria Bonita & 4.53 & 7.93 & 5.94 & 15.59 & $8.50 \mathrm{~b}$ \\
\hline Genovese & 7.66 & 11.26 & 15.89 & 10.45 & $11.32 \mathrm{a}$ \\
\hline Means & $6.10 \mathrm{C}$ & $9.60 \mathrm{~B}$ & $10.92 \mathrm{~B}$ & $13.02 \mathrm{~A}$ & \\
\hline$F_{\text {value for variety }}$ & $16.994 *$ & $\mathbf{F}_{\text {value for fertilizer }}$ & $18.073 *$ & & \\
\hline
\end{tabular}

Means followed by different uppercase letters in the line and lowercase letters in the column differ by the Tukey test $(\mathrm{p}<0.05) ; *=$ significant; ns = no significant

Table 2. Means of plant height, biomass yield, concentration and yield of essential oil of Ocimum basilicum L. varieties at field cultivation.

\begin{tabular}{|c|c|c|c|c|c|}
\hline FIELD & & Height (cm) & & & \\
\hline Varieties & $100 \%$ Organo-mineral & $50 \%$ Organo-mineral & Mineral & Organic & Means \\
\hline Maria Bonita & 62.15 & 60.37 & 61.36 & 59.83 & $60.93 b$ \\
\hline Genovese & 84.33 & 86.91 & 86.64 & 158.80 & $104.17 \mathrm{a}$ \\
\hline Means & 73.64 & 73.24 & 74.00 & 109.31 & \\
\hline$F_{\text {value for variety }}$ & $4.571 *$ & $\mathbf{F}_{\text {value for fertilizer }}$ & $0.779^{\mathrm{ns}}$ & & \\
\hline \multicolumn{6}{|c|}{ Biomass yield (g plant ${ }^{-1}$ ) } \\
\hline Maria Bonita & 980.00 & 923.66 & 640.00 & 926.66 & $867.58 b$ \\
\hline Genovese & 1463.00 & 1446.66 & 1360.33 & 1409.66 & $1419.91 \mathrm{a}$ \\
\hline Means & $1221.50 \mathrm{~A}$ & $1185.16 \mathrm{~A}$ & $1000.16 \mathrm{~B}$ & $1168.16 \mathrm{~A}$ & \\
\hline$F_{\text {value for variety }}$ & $13.849 *$ & $\mathbf{F}_{\text {value for fertilizer }}$ & $3.288^{*}$ & & \\
\hline \multicolumn{6}{|c|}{ Essential oil content $(\%)$} \\
\hline Maria Bonita & 1.68 & 1.43 & 1.42 & 1.40 & 1.48 \\
\hline Genovese & 0.88 & 1.50 & 1.32 & 1.05 & 1.19 \\
\hline Means & 1.28 & 1.47 & 1.37 & 1.22 & \\
\hline$F_{\text {value for variety }}$ & $0.512^{\mathrm{ns}}$ & $F_{\text {value for fertilizer }}$ & $0.658^{\mathrm{ns}}$ & & \\
\hline \multicolumn{6}{|c|}{ Essential oil yield (g plant ${ }^{-1}$ ) } \\
\hline Maria Bonita & 16.55 & 13.08 & 9.08 & 13.23 & $12.98 b$ \\
\hline Genovese & 12.81 & 21.86 & 18.04 & 14.99 & $16.93 \mathrm{a}$ \\
\hline Means & 14.68 & 17.47 & 13.56 & 14.11 & \\
\hline $\mathbf{F}_{\text {value for variety }}$ & $4.281 *$ & $\mathbf{F}_{\text {value for fertilizer }}$ & $0.830^{\mathrm{ns}}$ & & \\
\hline
\end{tabular}

Means followed by different uppercase letters in the line and lowercase letters in the column differ by the Tukey test $(\mathrm{p}<0.05) ; *=$ significant; ns = no significant; 


\section{Essential oil chemical composition}

The analysis of the essential oil compounds of the two varieties is presented in Tables 3. The major compounds found in the Maria Bonita genotype were linalool, geraniol and 1,8-cineol. For the Genovese genotype, the compounds linalol, methyl chavicol and 1,8-cineol were the main majority structures.

Table 3. General means of chemical compounds found in Maria Bonita genotype essential oil under different environments of production

\begin{tabular}{|c|c|c|c|c|c|c|c|c|c|}
\hline \multirow{3}{*}{ Peak } & \multirow{3}{*}{ Compound } & \multirow{2}{*}{\multicolumn{2}{|c|}{$\mathrm{IRR} \mathrm{Calc}^{2}$}} & \multirow{2}{*}{\multicolumn{2}{|c|}{ IRR $\mathrm{Lit}^{3}$}} & \multirow{2}{*}{\multicolumn{2}{|c|}{$\frac{\text { FIELD }}{\% \text { FID }}$}} & \multicolumn{2}{|c|}{ GREENHOUSE } \\
\hline & & & & & & & & & \\
\hline & & $\begin{array}{l}\text { Maria } \\
\text { Bonita }\end{array}$ & Genovese & $\begin{array}{l}\text { Maria } \\
\text { Bonita }\end{array}$ & Genovese & $\begin{array}{l}\text { Maria } \\
\text { Bonita }\end{array}$ & Genovese & $\begin{array}{l}\text { Maria } \\
\text { Bonita }\end{array}$ & Genovese \\
\hline 1 & a-pinene & 924 & 923 & 932 & 932 & 0,12 & 0.26 & 0,14 & 0.44 \\
\hline 2 & sabinene & 962 & 962 & 969 & 969 & 0,18 & 0.55 & 0,14 & 0.37 \\
\hline 3 & b-pinene & 967 & 967 & 974 & 974 & 0,48 & 0.34 & 0,53 & 0.80 \\
\hline 4 & 1,8-cineol & 1021 & 1022 & 1026 & 1026 & 4,94 & 6.6 & 4,95 & 9.16 \\
\hline 5 & (Z)-sab. hydrate & 1056 & 1057 & 1065 & 1065 & 0,10 & 0.27 & 0,20 & 0.19 \\
\hline 6 & cis-linalool oxide & 1061 & - & 1067 & - & 0,10 & - & 0,40 & - \\
\hline 7 & terpinolen & 1077 & 1077 & 1086 & 1086 & 0,10 & 0.27 & 0,16 & 0.12 \\
\hline 8 & linalool & 1092 & 1093 & 1095 & 1095 & 82,95 & 72.16 & 79,90 & 69.81 \\
\hline 9 & borneol & 1158 & 1158 & 1165 & 1165 & 0,16 & 0.45 & 0,98 & 0.46 \\
\hline 10 & a-terpineol & 1181 & 1181 & 1186 & 1186 & 0,35 & 0.19 & 0,68 & 0.41 \\
\hline 11 & neral & 1229 & - & 1235 & - & 0,10 & - & 0,20 & - \\
\hline 12 & geraniol & 1241 & - & 1249 & - & 6,84 & - & 9,26 & - \\
\hline 13 & geranial & 1258 & - & 1264 & - & 0,59 & - & 0,21 & - \\
\hline 14 & bornyl acetate & 1276 & 1276 & 1287 & 1287 & 0,56 & 0.53 & 1,66 & 0.71 \\
\hline 15 & b-elemeno & 1382 & 1383 & 1389 & 1389 & 0,36 & 0.15 & 0,17 & 0.64 \\
\hline 16 & (E)-caryophyllene & 1415 & - & 1417 & - & 0,17 & - & 0,48 & - \\
\hline 17 & $\begin{array}{c}\mathrm{a}-(\mathrm{E})- \\
\text { bergamotene }\end{array}$ & 1424 & 1425 & 1432 & 1432 & 1,19 & 0.16 & 0,13 & 0.68 \\
\hline 18 & germacrene D & 1476 & 1477 & 1484 & 1484 & 0,39 & 0.26 & 0,45 & 0.65 \\
\hline 19 & a-bulnesene & 1499 & 1499 & 1509 & 1509 & 0,10 & 0.55 & 1,14 & 0.24 \\
\hline 20 & camphene & - & 939 & - & 946 & - & 0.23 & - & 0.13 \\
\hline 21 & myrcene & - & 978 & - & 988 & - & 0.10 & - & 0.51 \\
\hline 22 & limonene & - & 1019 & - & 1024 & - & 0.26 & - & 0.23 \\
\hline 23 & (Z)-b-ocimene & - & 1035 & - & 1032 & - & 0.26 & - & 0.24 \\
\hline 24 & $\begin{array}{l}\text { (Z)-epoxi- } \\
\text { ocimene }\end{array}$ & - & 1129 & - & 1128 & - & 0.16 & - & 0.19 \\
\hline 25 & camphor & - & 1137 & - & 1141 & - & 0.26 & - & 0.31 \\
\hline 26 & terpinen-4-ol & - & 1169 & - & 1174 & - & 0.5 & - & 0.24 \\
\hline 27 & chavicol methyl & - & 1189 & - & 1195 & - & 15 & - & 11.03 \\
\hline 28 & a-guaiene & - & 1430 & - & 1437 & - & 0.41 & - & 0.26 \\
\hline 29 & a-humulene & - & 1450 & - & 1452 & - & 1.03 & - & 0.17 \\
\hline 30 & biciclogermacrene & - & 1492 & - & 1500 & - & 0.23 & - & 0.14 \\
\hline
\end{tabular}

${ }^{1}$ Retention time; ${ }^{2}$ IRR Calc: Relative Retention Index - calculated; ${ }^{3}$ IRRLit: Relative Retention Index - literature

The analysis of the major compounds showed a significant interaction between fertilizer sources and varieties (Table 4). 1,8-cineol presented a higher percentage using $50 \%$ of organo-mineral with the Genovese in the greenhouse. In the field, the highest value was found with the Genovese using $100 \%$ of the organo-mineral dose.

Linalool compound presented the highest percentage using $50 \%$ of organo-mineral dose and with organic fertilization with the Maria Bonita inside the greenhouse. In the field, the highest value was found with the same cultivar and also with $50 \%$ of the organo-mineral dose. The lowest percentages in the field were obtained with mineral fertilization and with Genovese cultivar. 
Table 4. Means of 1,8-cineol and linalool of the Ocimum basilicum L. varieties essential oil at greenhouse and field cultivation.

\begin{tabular}{|c|c|c|c|c|c|}
\hline GREENHOUSE & & 1,8-cineol \% & & & \\
\hline Varieties & $\begin{array}{c}100 \% \\
\text { Organo-mineral }\end{array}$ & $\begin{array}{c}\mathbf{5 0 \%} \\
\text { Organo-mineral }\end{array}$ & Mineral & Organic & Means \\
\hline Maria Bonita & $4.87 \mathrm{Bb}$ & $5.21 \mathrm{Ab}$ & $4.38 \mathrm{Db}$ & $5.01 \mathrm{Cb}$ & 4.87 \\
\hline Genovese & $7.09 \mathrm{Ba}$ & 9.49Aa & $4.90 \mathrm{Da}$ & $5.49 \mathrm{Ca}$ & 6.74 \\
\hline Means & 5.98 & 7.35 & 4.64 & 5.25 & \\
\hline $\mathbf{F}_{\text {value for interaction }}$ & $29475.647 *$ & & & & \\
\hline FIELD & & 1,8-cineol \% & & & \\
\hline Maria Bonita & $5.76 \mathrm{Ab}$ & $5.78 \mathrm{Ab}$ & $5.63 \mathrm{Bb}$ & $5.45 \mathrm{Ca}$ & 5.65 \\
\hline Genovese & 7.37Aa & $6.60 \mathrm{Ba}$ & $5.78 \mathrm{Ca}$ & $5.42 \mathrm{Db}$ & 6.29 \\
\hline Means & 6.57 & 6.19 & 5.70 & 5.43 & \\
\hline $\mathbf{F}_{\text {value for interaction }}$ & $6053.535^{*}$ & & & & \\
\hline GREENHOUSE & & Linalool & & & \\
\hline Varieties & $\begin{array}{c}100 \% \\
\text { Organo-mineral }\end{array}$ & $\begin{array}{c}\mathbf{5 0 \%} \\
\text { Organo-mineral } \\
\end{array}$ & Mineral & Organic & Means \\
\hline Maria Bonita & $77.55 \mathrm{Ba}$ & $79.35 \mathrm{Aa}$ & $74.51 \mathrm{Ca}$ & $79.29 \mathrm{Aa}$ & 77.67 \\
\hline Genovese & $74.78 \mathrm{Ab}$ & $53.21 \mathrm{Db}$ & $64.75 \mathrm{Bb}$ & $59.87 \mathrm{Cb}$ & 63.15 \\
\hline Means & 76.16 & 66.28 & 69.63 & 69.58 & \\
\hline $\mathbf{F}_{\text {value for interaction }}$ & $43193.756^{*}$ & & & & \\
\hline FIELD & & Linalool & & & \\
\hline Maria Bonita & $80.78 \mathrm{Da}$ & $83.78 \mathrm{Aa}$ & $83.02 \mathrm{Ba}$ & $82.05 \mathrm{Ca}$ & 82.40 \\
\hline Genovese & 73.19Ab & $72.16 \mathrm{Bb}$ & $61.55 \mathrm{Db}$ & $72.12 \mathrm{Cb}$ & 69.76 \\
\hline Means & 76.99 & 77.97 & 72.28 & 77.08 & \\
\hline
\end{tabular}

F $_{\text {value for interaction } \quad 1944440.671 *}$

Means followed by different uppercase letters in the line and lowercase letters in the column differ by the Tukey test $(\mathrm{p}<0.05)$; $*$ significant

\section{DISCUSSION}

\section{Height, fresh biomass, essential oil content and yield}

Genovese showed better performance than Maria Bonita. These results indicate the good adaptation of this Italian cultivar in Brazil, with the possibility of its cultivation in tropical regions, as well as being a new variety option of basil to supply markets and industries.

However, Maria Bonita presented greater tolerance to water stress than Genovese according to Vargas (2007), and better performance in other regions of higher temperature and lower humidity (BLANK et al., 2007).

The protected cultivation showed that the sources of mineral and organic fertilizers led to the best performance of the varieties in relation to the organo-mineral source, probably because the fertilizers differentially released the nutrients to the soil solution, more quickly or more slowly, during the period of cultivation.
As the experiment was carried out in the rainy season, plastic protection and controlled irrigation inside the greenhouse influenced the release and the nutrients supply from fertilization, and in this case, mineral fertilization due to its formulation took place more quickly.

For the field conditions, the organo-mineral and organic fertilization had better performance probably because it provided greater nutrients availability during the time of the experiments. The high soil humidity caused by the rainy period certainly led to greater leaching of the nutrients of the other sources, and the organo-mineral and organic formulation kept a larger quantity of nutrients around the root system of the basil plants.

In another view, as the organo-mineral fertilizer is prepared with mineral synthesis with organic matter, the nitrogen from this source works with controlled availability, while the nitrogen of the mineral fertilizer has a ready assimilation. Therefore, the cultivation time of varieties of aromatic species, between soil preparation and harvesting, should be considered for a better crop 
yield, as well as irrigation management and soil type.

However, it is known that there are proven advantages of using fertilizers in combination formulations. Pandey et al. (2016), in an analysis of the combined use of carbonized biomass (rich in organic carbon) and chemical fertilizers, observed an increase in plant biomass and yield of basil essential oil in two successive years of cultivation (2013 and 2014). In this case, the organo-mineral fertilizer provides the nutrients supply for a longer period.

Organic sources compared to chemical fertilizers have lower nutrient content and slow release, but are as effective as chemical fertilizers (NAGUIB, 2011), especially for the activation and conservation of the soil microbiota responsible for the release of nutrients to plants.

In organic fertilization, which also provided a favorable yield for the varieties, the nitrogen available in the soil comes from the processes of organic matter decomposition (organic acids and humins), through the biological fixation of saprophytic bacteria. These microorganisms act between the nitrification and mineralization processes of ammoniacal formulas, making $\mathrm{N}$ slowly available to plants (KIEHL, 2008).

Moreover, this process activates the microbiota of the soil and increases the number of negative charges between the clay minerals, which result in a higher cation exchange capacity, a better solution $\mathrm{pH}$ balance and a higher moisture retention (SILVA, 2017a). For basil, the presence of amino acids in organic fertilizers induced an increase in free radical scavenging activities (AZZA; YOUSEF, 2015).

There is currently a tendency to consider organic cultivation and organic matter content in the soil, especially in tropical crops, as a soil conditioner and natural fertility indicator. Therefore, the choice of the fertilizer can be related to the improvement of the soil conditions and the greater presence of the nutrients during a longer period of cultivation.

For the essential oil content, our findings are in accordance to other studies. Kamada et al. (1999) studying phenotypic plasticity in three accessions of basil, observed essential oil contents between 0.71 and $2.07 \%$, and low values of heritability for this character, due to strong environmental influence. Nalepa; Carvalho (2007) mentioned that the essential oil content is genetically controlled, but it can be influenced by the external environment.

In our experiment, high essential oil content was found in field, which also led to a higher yield of essential oil. In this area, there was the greater light available for photosynthesis reactions in the leaves, and consequently higher production of secondary metabolites. Morais (2009) said that luminous intensity is a factor that influences the concentration as well as the chemical composition of the essential oils. As an example, for the development of glandular trichomes, plant structures that biosynthesize and store the essential oil, a greater presence of light is necessary, a fact that was observed in the present work.

Taiz; Zeiger (2013) mentioned that the higher production of secondary metabolites under high levels of solar radiation is explained due to the fact that biosynthetic reactions are dependent on carbon skeleton supplies, made by photosynthetic processes and energy compounds that participate in the regulation reactions.

\section{Essential oil chemical composition}

At the present study, linalool was the major compound of both varieties, being highest in Maria Bonita. This is the compound having most interest by the pharmaceutical and chemical industries, because these varieties are excellents sources as a natural supply of this compound.

Luz et al. (2014) in evaluating the production of biomass and essential oil of basil (Ocimum basilicum L.) in different cultivation environments, observed that the chemical composition of the oil was the same for both the plants grown in the field. and those grown in a protected environment, and that the three active principles most produced by the cultivar were linalool $(76.44 \%)$, geraniol $(11.38 \%)$ and 1,8 -cineol $(5.4 \%)$, corroborating the results found in the present study but with different percentages.

For Blank et al. (2007), with respect to the linalool content $(\%)$, the cultivar Maria Bonita presented a stable behavior, in the years evaluated, and like the control, with a mean of $78.12 \%$ of linalool and colorless oil. Continuing the studies of the compounds present in the Maria Bonita oil, Blank et. al (2007), found that the geraniol content (\%) was $8.27 \%$ in the mean of the years, well above the Genovese control, and presented $8.77 \%$ of 1,8 cineol.

Studies carried out by Sajjadi (2006) when analyzing two $O$. basilicum genotypes from Iran, obtained essential oil content ranging from 0.2 to $0.5 \%$, and chromatographic results indicated methyl-chavicol as the major component ranging from 40.5 to $52.4 \%$ and linalool with $20.1 \%$ in only one of the cultivars, Purple variety.

The presence or absence of a compound or another may be linked, in addition to the genetic 
factors of each plant, to the type of environment to which it was submitted, which could explain the fact of higher geraniol content, in contrast to the reduction of linalool.

The essential oil chemical composition again showed that the organic and organo-mineral fertilizers can provide better conditions to the soil nutrition, because also these sources led to the high content of the majority compounds of the varieties studied.

It is also worth mentioning that the supply of micronutrients through organic fertilization possibly led to higher production of compounds of interest in the essential oil, since such nutrients as Zinc and Manganese stimulate the route of production of secondary metabolites in secondary plant metabolism.

\section{CONCLUSION}

Genovese presents better performance in the studied environmental conditions, considering height, fresh biomass and essential oil yield in relation to the Maria Bonita genotype.

The environment of cultivation and the way fertilizer sources release the nutrients can be a determinant factor in the performance of sweet basil.

Without protected cultivation, organic and organo-mineral fertilization provides better conditions for nutrient supply and plant development mainly in the rainy season.

The essential oil content of the plants is higher without protected cultivation, but the yield of essential oil as a function of the biomass can be the same.

\section{ACKNOWLEDGEMENT}

Thanks to FAPEMIG, CNPq and CAPES to financial support this work.

RESUMO: O manjericão (Ocimum basilicum L.) é uma cultura aromática e medicinal que produz metabolitos ricos em constituintes químicos para vários fins. A composição do óleo essencial é variável com fatores externos durante a produção, como fertilização e meio ambiente, podendo variar até mesmo entre os genótipos de uma espécie. Para melhor compreensão sobre o rendimento de biomassa e óleo essencial e manejo de nutrientes no cultivo de manjericão são necessários mais estudos. Dessa forma, o objetivo deste estudo foi avaliar o rendimento de biomassa e óleo essencial de variedades de manjericão com fertilizante organomineral em diferentes sistemas agrícolas. O delineamento experimental foi o de blocos casualizados (DBC), com três repetições, em esquema fatorial 2X4, com duas variedades (Maria Bonita e Genovese) e quatro fertilizações (50 e 100\% organomineral, uma fonte mineral e uma fonte orgânica). Duas áreas foram realizadas simultaneamente (estufa e campo) para avaliar a altura da planta, biomassa fresca, teor de óleo essencial, rendimento e composição química. Os resultados indicam que Genovese apresentou altura e rendimento de biomassa superior quando o fertilizante mineral ou orgânico foi utilizado na estufa. Os fertilizantes organominerais e orgânicos proporcionaram resultados significativamente melhores do rendimento de biomassa em ambas as variedades no cultivo de campo. O teor de óleo foi maior no campo, refletindo maiores rendimentos de óleo em tratamentos de campo em comparação com estufa. Concluímos que o ambiente de cultivo e a forma como as fontes de fertilizantes liberam os nutrientes podem ser fatores determinantes no desempenho das plantas de manjericão; sem cultivo protegido, o teor de óleo essencial é maior e o fertilizante organomineral pode fornecer um melhor suprimento de nutrientes para as plantas principalmente durante a estação chuvosa.

PALAVRAS-CHAVE: Plantas aromáticas. Disponibilidade de nutrientes. Fertilizantes organominerais.

\section{REFERENCES}

ADAMS, R. P. Identification of essential oil components by gas chromatography/mass spectroscopy. Carol Stream: Allured Publishing Corporation, 1995. 469p.

ARAB, A.; ZAMANI, G. R.; SAYYARI, M. H.; ASILI, J. Effects of chemical and biological fertilizers on morpho-physiological traits of marigold (Calendula officinalis L.). European Journal of Medicinal Plants, v. 8, p. 60-68, 2015. https://doi.org/10.9734/EJMP/2015/16697 
AZZA, S. M.; YOUSEF, R. S.; Response of basil plant (Ocimum sanctum L.) to foliar spray with amino acids or seaweed extract. International Journal of Horticultural Science and Ornamental Plants, v. 7, p. 94, 2015.

BLANK, A. F.; SOUZA, E. M.; ARRIGONI-BLANK, M. F.; PAULA, J. W. A.; ALVES, P. B. Maria Bonita: cultivar de manjericão tipo linalol. Pesquisa Agropecuária Brasileira, v. 42, n. 12, p. 1811-1813, 2007. https://doi.org/10.1590/S0100-204X2007001200020

BUFALO, J.; CANTRELL, C. L.; ASTATKIE, T.; ZHELJAZKOV, V. D. GAWDE, A.; BOARO, C. S. F. Organic versus conventional fertilization effects on sweet basil (Ocimum basilicum L.) growth in a greenhouse system. Industrial Crops and Products, v. 74, p. 249-254, 2015.

https://doi.org/10.1016/j.indcrop.2015.04.032

CERRI, C. E., 2011. Eficiência agronômica dos organominerais. Informe Abisolo.

CHEN, R.; ZHONG, L.; JING, Z.; GUO, Z.; LI, Z.; LIN, X.; FENG, Y. Fertilization decreases compositional variation of paddy bacterial community across geographical gradient. Soil Biology \& Biochemistry, v. 114, p. 181-188, 2017. https://doi.org/10.1016/j.soilbio.2017.07.013

DEMISSIE, Z. A.; SARKER, L. S.; MAHMOUD, S. S. Cloning and functional characterization of $\beta$ phellandrene synthase from Lavandula angustifolia. Planta, v. 233, p. 685-696, 2011.

https://doi.org/10.1007/s00425-010-1332-5

EHLERT, P. A. D.; BLANK, A. F.; ARRIGONI-BLANK, M. F.; PAULA, J. W. A.; CAMPOS, D. A.; ALVINO, C.S. Tempo de hidrodestilação na extração de óleo essencial de sete espécies de plantas medicinais. Revista Brasileira de Plantas Medicinais, v. 8, p. 79-80, 2006.

JI, J. H.; HOU, H. Q.; LIU, Y. R.; XIUMEI, L.; ZHAOBIN, F.; GUANGRONG, L.; TAO, Y.; WENJUAN, L. Effects of long-term fertilization on yield variation trend, yield stability and sustainability in the double cropping rice system. Acta Pedologica Sinica, v. 52, p. 607-619, 2015.

KAMADA, T.; CASALI, V. W. D.; BARBOSA, L. C. A.; FORTES, I. C. P.; FINGER, F. L. Plasticidade fenotípica de óleo essencial em acessos de manjericão (Ocimum basilicum L.). Revista Brasileira de Plantas Medicinais, v. 1, n. 2, p. 13-22, 1999.

KIEHL, E. J. Fertilizantes organominerais. Piracicaba: E. J. Kiehl. 160p. 2008.

LUZ, J. M. Q.; RESENDE, R. F.; SILVA, S. M.; SANTANA, D. G.; CAMILO, J. S.; BLANK, A. F.; HABER, L. L. Produção de óleo essencial de Ocimum basilicum L. em diferentes épocas, sistemas de cultlivo e adubações. Boletín Latinoamericano y del Caribe de Plantas Medicinales y Aromáticas, v. 13, n. 1, p. 69 80, 2014.

MCNAUGHTON V. Lavender: the grower's guide. Portland (USA): Timber Press, 2006. 192 p.

MIRZAJANI, Z.; HADAVI, E.; KASHI, A. Changes in the essential oil content selected traits of sweet basil (Ocimum basilicum L.) as induced by foliar sprays of citric acid and salicylic acid. Industrial Crops and Products, v. 76, p. 269-274, 2015. https://doi.org/10.1016/j.indcrop.2015.06.052

MORAIS, L. A. S. Influência dos fatores abióticos na composição química dos óleos essenciais. Horticultura Brasileira, v. 27, p. 4050-4063, 2009.

NAGUIB, N. Y. M. Organic versus chemical fertilization of medicinal plants: a concise review of researches. Advances in Environmental Biology, v. 3, p. 394-440, 2011. 
NALEPA, T.; CARVALHO, R. I. N. Produção de biomassa e rendimento de óleo essencial em camomila cultivada com diferentes doses de cama-de-aviário. Scientia Agraria, v. 8, p. 161 - 167, 2007. https://doi.org/10.5380/rsa.v8i2.8381

ONOFREI, V.; TELIBAN, G. C.; BURDUCE, M.; LOBIUC, A.; SANDU, C. B.; TOCAI, M.; ROBU, T. Organic foliar fertilization increases polyphenol content of Calendula officinalis L. Industrial Crops \& Products, v. 109, p. 509-513, 2017. https://doi.org/10.1016/j.indcrop.2017.08.055

ONWU, A. C.; ABUBAKAR, J. R.; UNAH, P. O. Effect of poultry manure on growth, yield of okra and soil properties in Makurdi, North Central Nigeria. International Journal of Agriculture Food Science, v. 4, p. 9 $12,2014$.

PANDEY, V.; PATEL, A.; PATRA, D. D. Integrated nutrient regimes ameliorate crop productivity, nutritive value, antioxidant activity and volatiles in basil (Ocimum basilicum L.). Industrial Crops \& Products, v. 87, p. 124-131, 2016. https://doi.org/10.1016/j.indcrop.2016.04.035

POPOVIĆ, Z.; KOSTIĆ, M.; STANKOVIĆ, S.; MILANOVIĆ, S.; SIVČEV, I.; KOSTIĆ, I.; KLJAJIĆ, P. Ecologically acceptable usage of derivatives of essential oil of sweet basil, O. basilicum, as antifeedants against larvae of the gypsy moth, L. dispar. Journal of Insect Science, v. 13, n. 161, p. 01-12, 2013.

PRADEEPKUMAR, T.; BONNY, B.P.; MIDHILA, R.; JOHN, J.; DIVYA, M. R.; ROCH, C. V. Effect of organic and inorganic nutrient sources on the yield of selected tropical vegetables. Scientia Horticulturae, $\mathbf{v}$. 224, p. 84-92, 2017. https://doi.org/10.1016/j.scienta.2017.04.022

RAFIEE, H.; MEHRAFARIN, A.; QADERI, A.; JARI, S. K.; BADI, H. N. Phytochemical, Agronomical and Morphological Responses of Pot Marigold (Calendula officinalis L.) to Foliar Application of Bio-stimulators (Bioactive Amino Acid Compounds). Journal of Medicinal plants, v. 3, n. 47, p. 48-61, 2013.

RAIJ, B. VAN. Fertilidade do solo e manejo de nutrientes. Piracicaba: International Plant Nutrition Institute, 2011. 420p.

RIBEIRO, P. G. F.; DINIZ, R. C. Plantas aromáticas e medicinais: cultivo e utilização. Londrina: IAPAR, 2008. $218 \mathrm{p}$.

SAJJADI, S. E. Analysis of the essential oils of two cultivated basil (Ocimum basilicum L.) from Iran. Journal of Pharmaceutical Sciences, v. 14, n. 3, p. 128-130, 2006.

SELLAMI, I. H.; MAAMOURI, E.; CHAHED, T.; WANNES, W. A.; KCHOUK, M. E.; MARZOUK, B. Effect of growth stage on the content and composition of the óleo essencial and phenolic fraction of sweet marjoram (Origanum majorana L.). Industrial Crops \& Products, v. 30, p. 395-402, 2009.

https://doi.org/10.1016/j.indcrop.2009.07.010

SILVA, S. M.; CUNHA, J. P. A. R.; CARVALHO, S.M.; ZANDONADI, C. H. S.; MARTINS, R. C.; CHANG, R. Ocimum basilicum essential oil combined with deltamethrin to improve the management of Spodoptera frugiperda. Ciência e Agrotecnologia, v. 41, n. 6, p. 665-675, 2017 a.

https://doi.org/10.1590/1413-70542017416016317

SILVA, S. M.; LUZ, J. M. Q.; NOGUEIRA, P. A. M.; BLANK, A. F.; SAMPAIO, T. S.; PINTO, J. A. O.; WISNIEWSKI, A. Organo-mineral fertilization effects on biomass and essential oil of lavender ( Lavandula dentata L.). Industrial Crops \& Products, v. 103, p. 133-140, 2017 b.

https://doi.org/10.1016/j.indcrop.2017.04.004

SINGH, K.; CHAND, S.; YASEEN, M. Integrated nutrient management in Maria Bonita(Ocimum basilicum). Industrial Crops \& Products, v. 55, p. 225-229, 2014. https://doi.org/10.1016/j.indcrop.2014.02.009 
TAIZ, L.; ZEIGEL, E. Fisiologia Vegetal. 4. ed. Porto Alegre: Armed, 2013. 820 p.

VAN DEN DOOL, H.; KRATZ, P. D. Generalization of the retention index system including linear temperature programmed gas-liquid partition chromatography. Journal of Chromatography, v. 11, p. 463-71, 1963. https://doi.org/10.1016/S0021-9673(01)80947-X

VARGAS, M. E. O. Reposts ecophysiological and biochemical of the Ocimum Basilicum cultivate under water deficit. 2007. 87 f. Dissertação (Mestrado em Agroecossistemas) - Universidade Federal de Sergipe, São Cristóvão, 2007. 